\title{
DIETS FOR FEED TRAINING PEACOCK BASS Cichla sp.
}

\author{
José Eurico Possebon Cyrino ${ }^{1 *}$; Fernando Kubitza ${ }^{2}$ \\ ${ }^{1}$ USP/ESALQ -Depto. de Produção Animal, C.P. 9 - 13418-900 - Piracicaba, SP - Brasil. \\ 'Acqua\&Imagem Serviços / CERAQUA, C.P. 01 - 49900-000 - Própria, SE - Brasil. \\ *Corresponding author <jepcyrin@esalq.usp.br>
}

\begin{abstract}
The use of prized, carnivorous fish species such as the peacock bass Cichla sp. in either intensive farming or sport fishing demand specific knowledge on feed conditioning strategies for those species. One thousand and fifteen 0.5 -g fingerlings were trained for 7 days to feed on ground fish flesh (GF). Seven hundred and seventy six $(76 \%)$ fish $(0.63 \pm 0.03 \mathrm{~g})$ feeding on GF were stocked into twelve $0.03-\mathrm{m}^{3}$ net cages $(63 \mathrm{fish} /$ cage) and submitted to gradual feed ingredient transition (GFIT) weaning technique. Moist pellets with 90, 80, 70 or $60 \%$ GF (GF-90, GF-80, GF-70 or GF-60, respectively) were offered during the first 4 days of GFIT. No fish accepted GF-00 at the end of GFIT. Fish started on GF-90 or GF-80 fed well until GF dietary levels dropped below $40 \%$. To improve acceptance of pellets containing $30 \%$ or less GF, a second trial with four $0.03-\mathrm{m}^{3}$ net cages stocked with 120, 0.5-g fish feeding on GF was designed. Fish fed on a sequence of moist pellets containing $90,80,70,60,50$ or $40 \%$ GF for 3 days. Approximately $81 \%$ of the fish accepted GF-40; they were pooled and restocked into nine $0.03-\mathrm{m}^{3}$ net cages and weaned to GF-00 with a sequence of diets containing 30,20 and $10 \%$ GF plus: 1) a meat-flavored dry, commercial feed (MEAT); 2) a fish-flavored dry, commercial feed (FISH); or 3) MEAT plus $10 \%$ krill meal (KM). Fish accepted fish-flavored pellets better than meat-flavored pellets. Addition of $10 \%$ krill meal to a meat-flavored feed improved pellet acceptance, even when ground fish flesh comprised only $10 \%$ of the feed. However, no fish accepted GF-00 pellets at the end of this study.

Key words: culture methods, carnivorous fish, weaning diets, pelleted diets
\end{abstract}

\section{DIETAS PARA CONDICIONAMENTO ALIMENTAR DO TUCUNARÉ Cichla sp.}

\begin{abstract}
RESUMO: A produção comercial de peixes carnívoros como o tucunaré Cichla sp. depende do desenvolvimento de técnicas de condicionamento alimentar para cada espécie. Um mil e quinze alevinos de tucunaré Cichla sp. (peso médio 0,5 g) foram condicionados a aceitar alimento inerte na forma de filé de peixe moído (FP) por um período de 7 dias, com um sucesso de treinamento de $76 \%$ (771 peixes). Estes 771 peixes (peso médio $0,63 \pm 0,03 \mathrm{~g}$ ) foram estocados em 12 gaiolas de volume $0,03 \mathrm{~m}^{3}$ (63 peixes/gaiola) e condicionados a aceitar uma dieta seca (FP-00) pelo método da transição gradual dos ingredientes da ração (TGIR) recebendo, durante 4 dias, grânulos úmidos com 90, 80, 70 ou 60\% de FP (FP-90, FP-80, FP-70 ou FP-60, respectivamente). Nenhum peixe aceitou FP-00 no final da TGIR. Os peixes alimentados com FP-90 e FP-80 aceitaram bem as dietas enquanto a quantidade de FP não caiu para níveis inferiores a $40 \%$. Um segundo ensaio foi realizado visando melhorar a aceitação das dietas contendo $30 \%$ ou menos FP. Para tanto, quatro gaiolas de $0,03 \mathrm{~m}^{3}$ foram estocadas com 120 peixes cada (peso médio $0,5 \mathrm{~g}$ ), os quais foram inicialmente alimentados com FP e submetidos a TGIR com dietas FP-90, FP-80, FP-70, FP-60, FP-50 e FP-40 por períodos subsequentes de 3 dias. Os peixes que aceitaram GF-40 (81\% do total) foram agrupados e estocados em 9 gaiolas de $0,03 \mathrm{~m}^{3}$ e treinados por 3 dias a aceitar FP-00 pelo uso de dietas contendo 30, 20 ou $10 \%$ de FP e flavorizadas com: (1) alimento comercial seco sabor carne (ACSC); (2) alimento comercial seco sabor peixe (ACSP); ou (3) ACSC mais 10\% de farinha de krill (ACSP+FK). A aceitação de ACSP foi melhor que ACSC. A adição de KM ao ACSC melhorou a aceitabilidade da dieta em comparação com outros aditivos alimentares, mesmo quando a quantidade de FP nas dietas foi reduzida para $10 \%$. Entretanto, ao final dos ensaios, nenhum peixe aceitou grânulos alimentares isentos de FP (FP-00).

Palavra-chave: sistema de criação, peixes carnívoros, dietas de transição, dietas pelletizadas
\end{abstract}

\section{INTRODUCTION}

Brazilian aquaculture has experienced a significant growth in the last decade. Tropical climate in central, north and northeast Brazil, availability of land and water resources, production of grains and cereals for fish feeds, an enormous variety of fish species and a large, untapped domestic market for fishery products forecasts Brazil as a major supplier of cultured fish. Many Brazilian fish species with established markets are carnivores, and their intensive culture depends on the development of strategies to condition those species to accept commercial feeds. In addition, weaning juvenile, carnivore fish from natural food to dry pellets will provide research op- 
portunities to determine nutritional requirements for many species.

South American peacock bass Cichla sp., a Cichlid native to the Amazon River basin, fills an ecological position equivalent to largemouth bass Micropterus salmoides in North America. Both species have similar, piscivorous feeding preferences and general appearance. Feed training strategies for largemouth bass were developed in the United States (Snow, 1960; 1963; 1968; Kubitza \& Lovshin 1997a; 1997b). Strategies used to feed train largemouth bass may help conditioning Brazilian carnivores, including peacock bass, to accept dry diets.

Peacock bass can be potentially used either as sport, ornamental or food fish. The species has a white, firm-textured, boneless flesh and is considered one of the top table fish among Amazonian species. Peacock basses spawn naturally, several times a year in static water. While production of fingerlings in ponds is easily accomplished, few studies on weaning fingerling peacock bass from live food to formulated, dry feeds have been published (Fischer, 1991; Moura et al., 2000), and results were not very encouraging, ranging from 8 to $38 \%$ training success. The present study aimed to develop diets and feeding strategies for training peacock bass fingerlings to accept dry pellets.

\section{MATERIAL AND METHODS}

Peacock bass fry captured from a reservoir in the state of Goiás in Central Brazil were raised in fertilized ponds. One thousand and fifteen 0.5 -g fingerlings were seined from the ponds and stocked into a $0.8 \mathrm{~m}^{3}$ net-cage and fed with ground fish flesh to satiation, four to five times a day for 7 days. Seventy-six percent of these fish were trained to accept ground fish flesh, and were submitted to a series of trials aiming to wean them from ground fish flesh to a dry, pelleted diet.

\section{Trial 1}

Sixty-three $0.63 \pm 0.03 \mathrm{~g}$ peacock bass trained to feed on ground fish were stocked into each of twelve $0.03-\mathrm{m}^{3}$ net cages $(0.34 \mathrm{~m} \times 0.34 \mathrm{~m} \times 0.35 \mathrm{~m}$ depth) placed in a $112-\mathrm{m}^{3}$ concrete tank. Moist feeds with 90 , 80,70 or $60 \%$ ground fish flesh (GF-90, GF-80, GF-70 and GF-60, respectively) were compared as initial diets during gradual feed ingredient transition to dry pellet without ground fish (GF-00), in a completely randomized design trial $(n=3)$. The sequence of diets used during the gradual feed ingredient transition is shown in Table 1.

Weaning diets were prepared by grinding and mixing a $30 \%$ crude protein, commercial, dry, fish-flavored feed with ground whiting flesh. All diets were supplemented with vitamin mix at $1 \%$ of total ingredients and were extruded on electric meat mincer. Diets containing over $60 \%$ ground fish had paste-like texture and were fed to fish after passing through a $1.5-\mathrm{mm}$ screen sieve. Diets with $50 \%$ or less ground fish were presented to fish as $2 \mathrm{~mm}$ pellets. Dietary dry matter was determined after oven drying at $105^{\circ} \mathrm{C}$ for 24 hours. Percent composition of the weaning diets is detailed in Table 2.

Fish were fed the experimental diets to satiation four times a day. Each weaning diet was administered to fish for four days. Percent feeders were determined at each diet change during the weaning period by dividing the number of feeders by the total number of fish stocked. Feeders were identified at the end of the day based on their larger, distended abdomen, contrasting with the smaller size and emaciated appearance of the non-feeders. Percent feeders were used as indicator of survival rates. Non-feeders were removed from experimental units at each diet change.

Table 1 - Sequence of weaning diets containing ground fish flesh (GF) used during gradual feed ingredient transition for peacock bass.

\begin{tabular}{|c|c|c|c|c|c|c|}
\hline Initial diets & \multicolumn{5}{|c|}{ Weaning diets ${ }^{1}$} & Days \\
\hline GF-90 & GF-70 & GF-50 & GF-30 & GF-10 & GF-00 & 24 \\
\hline GF-80 & GF-60 & GF-40 & GF-20 & GF-00 & & 20 \\
\hline GF-70 & GF-50 & GF-30 & GF-10 & GF-00 & & 20 \\
\hline GF-60 & GF-40 & GF-20 & GF-00 & & & 16 \\
\hline
\end{tabular}

1 each diet was fed for 4 days

Table 2 - Percent composition of the weaning diets used during gradual feed ingredient transition for peacock bass.

\begin{tabular}{lcccccccccc}
\hline & \multicolumn{7}{c}{ Weaning diets containing decreasing levels of ground fish flesh (GF) } \\
\cline { 2 - 10 } Feed ingredients & GF-90 & GF-80 & GF-70 & GF-60 & GF-50 & GF-40 & GF-30 & GF-20 & GF-10 & GF-00 \\
\hline Ground fish flesh & 90.0 & 80.0 & 70.0 & 60.0 & 50.0 & 40.0 & 30.0 & 20.0 & 10.0 & - \\
Dry commercial feed & 9.0 & 19.0 & 29.0 & 39.0 & 49.0 & 39.0 & 39.0 & 39.0 & 49.0 & 59.0 \\
Sardine fish meal & - & - & - & - & - & 20.0 & 30.0 & 40.0 & 40.0 & 40.0 \\
Vitamin premix $^{1}$ & 1.0 & 1.0 & 1.0 & 1.0 & 1.0 & 1.0 & 1.0 & 1.0 & 1.0 & 1.0 \\
\hline
\end{tabular}

${ }^{1}$ Composition per kg of diet: vitamin A 36,000 UI, vitamin $B_{6} 9 \mathrm{mg}$, vitamin $\mathrm{D}_{3} 4,500 \mathrm{UI}$, vitamin E 150 UI, vitamin $\mathrm{B}_{12} 60 \mathrm{mg}$, vitamin $\mathrm{B}_{2} 6 \mu \mathrm{g}$, vitamin $\mathrm{K}_{3} 4.5 \mathrm{mg}$, folic acid $9 \mathrm{mg}$, biotin $0.6 \mathrm{mg}$, pantothenic acid $30 \mathrm{mg}$, niacin $90 \mathrm{mg}$, ascorbic acid 1,000 mg, thiamine $15 \mathrm{mg}$. ${ }^{2}$ Composition of the commercial feed: moisture $12.0 \%$; crude protein $30.0 \%$; lipids $9.0 \%$; crude fiber $4.5 \%$; ash $6.5 \%$; Ca $2.4 \%$; $\mathrm{P}$ $0.9 \%$. 
Morning (08h00) and afternoon (16h00) dissolved oxygen and water temperature were monitored daily. Average morning and afternoon values for dissolved oxygen and water temperature were $5.4 \pm 0.6$ and $8.9 \pm 1.8 \mathrm{mg} \mathrm{L}^{-1}$, and $24.3 \pm 0.8$ and $27.8 \pm 1.4^{\circ} \mathrm{C}$, respectively. Total ammonia nitrogen and afternoon $\mathrm{pH}$ were checked every two days with a water test kit (FF-2, HACH Company). Average values for total ammonia nitrogen and $\mathrm{pH}$ were $0.4 \pm 0.2 \mathrm{mg} \mathrm{L}^{-1}$, and $7.0 \pm 0.4$, respectively.

\section{Trial 2}

In Trial 1, fingerling peacock bass did not feed on pellets which have $30 \%$ or less ground fish flesh. Therefore, Trial 2 was set up aiming to enhance palatability of weaning diets with $30 \%$ or less ground fish and improve weaning success to a dry pellet without ground fish (GF-00). Peacock bass fingerlings which did not accept weaning diets in Trial 1 were pooled and maintained on a ground fish flesh diet for 5 additional days. At the end of this period, fish feeding on ground fish flesh $(0.51 \pm 0.02 \mathrm{~g}$ body weight $)$ were stocked into four, $0.03-\mathrm{m}^{3}$ net cages, 120 fish per cage. All fish were fed for three days with either GF-90, GF-80, GF-70, GF60 , GF-50 or GF-40 diets, in a gradual feed ingredient transition strategy. Percent feeders were determined at each diet change as previously described. Diets with $70 \%$ or more ground fish had paste-like texture and were fed as described in Trial 1. Diets with $60 \%$ or less ground fish were presented to the fish as $2-\mathrm{mm}$ pellets.

Peacock bass feeding on GF-40 were pooled and restocked into nine, $0.04-\mathrm{m}^{3}$ net cages, 42 fish per cage. Fish were weaned from GF-40 to GF-00 using three diet sequences $(\mathrm{n}=3)$, in a gradual feed ingredient transition (Table 3). Diets in the weaning sequence had 30, 20 and $10 \%$ ground fish and were flavored with either krill meal; a commercial, fish flavored feed or a commercial, meat flavored feed. Diets containing meat flavored feed served as control, since previous diets with 90 to $40 \%$ ground fish were prepared with the same commercial meat flavored feed. Diets with 40 to $90 \%$ ground fish had the same percent composition as diets used in Trial 1. The composition of diets with 10 to $30 \%$ ground fish is detailed in Table 4. The final dry pellet (GF-00) had the same composition as GF-00 used in Trial 1.

Average morning (08h00) and afternoon (16h00) values for dissolved oxygen and water temperature were $4.8 \pm 0.5$ and $9.2 \pm 1.3 \mathrm{mg} \mathrm{L}^{-1}$, and $26.2 \pm 1.0$ and $29.7 \pm 1.1^{\circ} \mathrm{C}$, respectively. Average values for total ammonia nitrogen and afternoon $\mathrm{pH}$ were $0.2 \pm 0.1 \mathrm{mg} \mathrm{L}^{-1}$, and $7.8 \pm 0.2$, respectively.

\section{Experimental designs and statistical analyses}

All trials were set up in a completely randomized design. Statistical analyses were performed using the Statistical Analysis System (SAS, 1985). Data on percent feeders were transformed when advised by SAS, using the arcsine of the square root procedure before submission to ANOVA or polinomial regression. Treatment means were compared using the protected LSD test $(\alpha=0.05)$ and orthogonal contrasts. Polinomial regression was used to test for the effect of ground fish flesh levels in the diet on percent feeders.

Table 3 - Sequence of diets used to wean fingerling peacock bass from a moist pellet containing $40 \%$ ground fish (GF-40) to a dry pellet without ground fish (GF-00).

\begin{tabular}{|c|c|c|c|c|}
\hline \multirow[b]{2}{*}{ Diet sequence } & \multicolumn{4}{|c|}{ Weaning diets ${ }^{1}$} \\
\hline & GF-30 & GF-20 & GF-10 & GF-00 \\
\hline Meat flavored & \multicolumn{3}{|c|}{ containing meat flavored feed } & GF-00 \\
\hline Fish flavored & \multicolumn{3}{|c|}{ containing fish flavored feed } & GF-00 \\
\hline Krill meal-KM & $10 \% \mathrm{KM}$ & $10 \% \mathrm{KM}$ & $10 \% \mathrm{KM}$ & GF-00 \\
\hline
\end{tabular}

${ }^{1}$ each diet was fed for 3 days.

Table 4 - Percent composition of the weaning diets containing 30, 20 or 10\% ground fish flesh (GF) flavored with either meat-flavored commercial dry feed (CDF meat), fish-flavored commercial dry feed (CDF fish) or 10\% krill meal used to wean peacock bass from a moist feed containing $40 \%$ ground fish flesh (GF-40) to a dry pellet without ground fish flesh (GF-00).

\begin{tabular}{|c|c|c|c|c|c|c|c|c|c|}
\hline \multirow[b]{3}{*}{ Ingredients } & \multicolumn{9}{|c|}{ Weaning diets } \\
\hline & \multicolumn{3}{|c|}{ GF-30 } & \multicolumn{3}{|c|}{ GF-20 } & \multicolumn{3}{|c|}{ GF-10 } \\
\hline & meat & fish & krill & meat & fish & krill & meat & fish & krill \\
\hline Ground fish & 30.0 & 30.0 & 30.0 & 20.0 & 20.0 & 20.0 & 10.0 & 10.0 & 10.0 \\
\hline CDF meat & 69.0 & - & 59.0 & 79.0 & - & 69.0 & 89.0 & - & 79.0 \\
\hline CDF fish & - & 69.0 & - & - & 79.0 & - & - & 89.0 & - \\
\hline krill meal & - & - & 10.0 & - & - & 10.0 & - & - & 10.0 \\
\hline Vitamin $\operatorname{mix}^{1}$ & 1.0 & 1.0 & 1.0 & 1.0 & 1.0 & 1.0 & 1.0 & 1.0 & 1.0 \\
\hline
\end{tabular}




\section{RESULTS}

\section{Trial 1}

After four days of weaning from 100\% GF (Table 5 ), the percentage of peacock basses accepting the prepared diets improved from 4 to $98 \%$ as the inclusion of ground fish flesh in the diets increased from 60 to $90 \%$ $(P<0.01)$. However, acceptance of pellets during weaning dropped significantly as the amount of ground fish flesh in the diets fell below $50 \%$ in GF-90 and $40 \%$ in GF-80 diets sequences. None of the weaning sequences yielded fish accepting dry pellets without fish flesh at the end of Trial 1 (Table 5).

\section{Trial 2}

Percent fish accepting prepared feeds decreased from 93 to $81 \%$ as the inclusion of ground fish flesh in diets was reduced from 90 to $40 \%(P<0.01)$ (Table 6). When the amount of ground fish flesh dropped to $10 \%$, the addition of $10 \%$ krill meal to the pellets maintained pellet acceptance at $81 \%$, while only $15 \%$ and $4 \%$ of peacock bass accepted the fish- or meat-flavored pellets, respectively $(P<0.05)$. Fish accepted fish-flavored pellets better than meat-flavored pellets without krill meal $(P<0.05)$. Although $81 \%$ of fish accepted GF-10 pellets flavored with $10 \%$ krill meal, removal of krill meal and fish flesh from the meat flavored GF-00 reduced feed acceptance to nearly zero. Acceptance of the final dry pellets with no krill or ground fish ranged from 0 to $2 \%$ and showed no difference among the tested weaning sequences $(P>0.05)$.

\section{DISCUSSION}

\section{Ground fish flesh as a starter diet for peacock bass}

Ground fish flesh combines adequate flavor and texture and proved to be an effective starter diet to feed training peacock bass, as $76 \%$ of the fish accepted ground fish flesh after seven days of training. Fischer (1991) weaned $100 \%$ of forty eight, $0.4-\mathrm{g}$ peacock basss from brine shrimp nauplii to ground fish flesh in 4 days. Snow $(1960 ; 1963 ; 1968)$ found that 39 to $97 \%$ of largemouth bass accepted ground fish flesh as a starter diet. Kubitza \& Lovshin (1997b) also reported 61 to $86 \%$ acceptance of ground fish flesh by 0.9 to $1 \mathrm{~g}$ largemouth bass.

\section{Weaning peacock bass from fish flesh to a dry pellet}

Fischer (1991) used gradual feed transition as a strategy to wean peacock bass fingerlings from ground fish flesh to moist pellet. Gradual feed transition consists of gradual replacement of ground fish flesh in moist pellets, feeding a progressively smaller amount of fish flesh and a larger amount of moist pellets. Weaning success was $38 \%$ when a commercial, microencapsulated diet was added to moist pellets as attractant, compared to only $8 \%$ for a moist pellet without attractant. Kubitza \& Lovshin (1997a) found gradual feed ingredient transition more effective than gradual feed transition to wean largemouth bass from freeze dried krill to dry pellets. Gradual feed ingredient transition successfully weaned $64 \%$ to $91 \%$ of largemouth basses from ground fish flesh to dry trout pellets (Kubitza \& Lovshin, 1997b). Detailed procedures for gradual feed transition and gradual feed ingredient transition are presented by Kubitza \& Lovshin (1997a).

Table 5 - Percent peacock bass fingerlings feeding on prepared feeds during 24 day of weaning from ground fish flesh to a dry pellet without fish flesh (GF-00). The weaning sequences started using diets with $90,80,70$ or $60 \%$ ground fish (GF-90, GF-80, GF-70 or GF-60, respectively), followed by diets with decreasing amounts of ground fish, as detailed.

\begin{tabular}{|c|c|c|c|c|c|c|c|c|}
\hline Sequen & ce of we & $\operatorname{aning} \mathrm{d}$ & ets used & in GFIT & & 4 days $^{1}$ & 8 days & 24 days \\
\hline GF-90 & GF-70 & GF-50 & GF-30 & GF-10 & $\mathrm{F}-00$ & 97.9 & 97.4 & 0.0 \\
\hline GF-80 & GF-60 & GF-40 & GF-20 & GF-00 & & 84.1 & 77.3 & - \\
\hline GF-70 & GF-50 & GF-30 & GF-10 & GF-00 & & 21.7 & 16.4 & - \\
\hline GF-60 & GF-40 & GF-20 & GF-00 & & & 4.2 & 1.1 & - \\
\hline
\end{tabular}

${ }^{1}$ Percent feeders $(\mathrm{Y})$ at day 4 was positively related to the levels of ground fish flesh $(\mathrm{X})(\mathrm{Y} / 100)^{1 / 2}=-2.4546+0.043654 \mathrm{X} ; \mathrm{R}^{2}=0.95$; $P<0.01)$.

Table 6 - Percent peacock bass fingelings accepting weaning diets with $30 \%$ or less ground fish (GF) flavored with either krill meal (KM), fish-flavored commercial dry feed or meat-flavored commercial dry feed. GF-00 was a dry pellet without $\mathrm{KM}$ or $\mathrm{GF}^{1}$.

\begin{tabular}{lcccc}
\hline Pellet flavor & GF-30 & GF-20 & GF-10 & GF-00 \\
\hline meat-flavored feed & 79.2 & $26.1 \mathrm{c}$ & $3.8 \mathrm{c}$ & 0.0 \\
fish-flavored feed & 80.8 & $59.3 \mathrm{~b}$ & $15.3 \mathrm{~b}$ & 1.9 \\
meat-flavored feed $+10 \%$ krill meal & 80.8 & $80.8 \mathrm{a}$ & $80.8 \mathrm{a}$ & 1.2 \\
\hline
\end{tabular}

${ }^{1}$ Means in the same column not sharing the same letters are significantly different (LSD; $P<0.05$ ).

${ }^{2}$ Each diet was fed for 3 days. 
In the present study, the texture and flavor of the weaning diets were gradually altered as ground fish flesh was progressively replaced by ground, commercial feed during gradual feed ingredient transition. Lowering the content of ground fish in the first weaning diet in Trial 1 was an attempt to speed up the weaning process. However, this procedure caused sudden changes in dietary flavor and/or texture, which may explain the decrease from $98 \%$ to $4 \%$ feed acceptance by peacock bass as the inclusion of ground fish in the first weaning diet was reduced from 90 to $60 \%$ (Table 5). Kubitza \& Lovshin (1997a) also observed a decrease in pellet acceptance after a sudden drop in the concentration of krill meal in the first feed used to wean fingerling largemouth bass from freeze dried krill to a dry pellet without krill meal.

Gradual feed ingredient transition worked relatively well as a weaning strategy for peacock bass. Sixty-six percent of peacock bass feeding on ground fish flesh accepted GF-30 when started on GF-90. Seventy-five percent of peacock basss were weaned from ground fish flesh to GF-40 when weaning began with GF-80. Decreasing the dietary levels of ground fish flesh below $30 \%$ resulted in poor feed acceptance. Dry pellets without ground fish flesh were not accepted by peacock bass in this study. Lowering ground fish flesh levels in diets to $40 \%$ or less coincided with 20 to $40 \%$ increase in the amount of fish meal added to diets. Most fish meal available in Brazil have peroxide values higher than 250 meq $\mathrm{kg}^{-1}$, indicating a high degree of rancidity. Additionally, raw material used to produce these meals include fish processing wastes, resulting in high levels of biogenic amines. Even though detailed analysis of the sardine meal used in Trial 1 was not performed, it is fair to infer that rancidity and/or biogenic amines possibly played a role in lowering feed palatability and acceptance by peacock bass.

\section{Enhancing feed palatability}

Peacock bass fingerlings were gradually weaned from ground fish to a semi-moist pellet containing $40 \%$ ground fish flesh with a success rate of $81 \%$. As observed in Trial 1, a sudden drop in feed acceptance was experienced when dietary ground fish flesh dropped below $40 \%$. Except for pellets flavored with krill meal, pellet acceptance was further reduced when dietary levels of ground fish flesh dropped to $20 \%$. Peacock bass accepted fish-flavored pellets better than meat-flavored pellets $(P<0.05)$. By the time peacock bass learned to accept moist pellets with $40 \%$ ground fish flesh, pellet flavor seemed more important than texture in determining the success of weaning to dry pellets. It shall be noted that hard pellets containing $10 \%$ ground fish flesh and flavored with krill meal were equally accepted or better than softer pellets containing $20 \%$ or $30 \%$ ground fish flesh without krill meal. Krill meal seemed to enhance pellet palatability for peacock bass. Removal of krill meal and ground fish flesh from the final dry pellet lowered feed acceptance to almost zero.
Kubitza \& Lovshin (1997a) found freeze dried krill and krill meal to be effective as attractants for feed training largemouth bass. Whole and crumbled freeze dried krill were accepted as a starter diet by 79 to $95 \%$ of 1-g largemouth bass. Krill meal enhanced flavor of dry pellets, increasing their acceptance by fish. Feeding response of red sea bream Pagrus major, Japanese eel Anguilla japonica, and gray mullet Mugil cephalus was improved when diets containing krill meal were offered (Allahpichay \& Shimizu, 1984).

This preliminary study showed the possibility of weaning peacock bass fingerlings from live food to formulated feeds. Detailed studies are needed on the palatability of weaning and final dry diets to eliminate ground fish flesh from diets used to grow peacock bass to larger sizes.

\section{ACKNOWLEDGEMENTS}

To FAPESP (São Paulo State Research Foundation) for providing financial support (proc. \# 95/095548). To Dr. Cyro F. Zinsly, a retired Professor at the Animal Science Department/ESALQ-USP for providing the feed ingredients and helping with feed preparation for this study. The authors also thanks Dr. Leonard L. Lovshin (Fisheries and Allied Aquacultures, Auburn University) for the critical review and suggestions to the manuscript.

\section{REFERENCES}

ALLAHPICHAY, I.; SHIMIZU, C. Supplemental effect of the whole body krill meal and the non-muscle krill meal of Euphausia superba in fish diet. Bulletin of the Japanese Society of Scientific Fisheries, v.50, p.815-820, 1984.

FISCHER, G.W. Acclimation to captivity, predatory characteristics and production economics of tucunaré, Cichla monoculus (Spix 1831) (Pisces: Cichlidae), including polyculture with tilapia, Oreochromis niloticus (L.) in Amazonian Ecuador. Corpus Christi, TX, 1991. 82p Dissertation (Doctoral) - Texas A \& M University.

KUBITZA, F.; LOVSHIN, L.L. The use of freeze dried krill to feed train largemouth bass Micropterus salmoides: feeds and training strategies. Aquaculture, v.148, p.299-312, 1997a.

KUBITZA, F.; LOVSHIN, L.L. Effects of initial weight and genetic strains on feed training of largemouth bass Micropterus salmoides using ground fish flesh and freeze dried krill as starter diets. Aquaculture, v.148, p.179-190, 1997b.

MOURA, M.A.M.; KUBITZA, F.; CYRINO, J.E.P. Feed training of peacock bass Cichla sp. Revista Brasileira de Biologia, v.60, p.645-654, 2000

SAS INSTITUTE. SAS user's guide: statistics. 5.ed. Cary: Statistical Analysis System Institute, 1985.

SNOW, J.R. An exploratory attempt to rear largemouth black bass fingerlings in a controlled environment. In: ANNUAL MEETING OFTHE SOUTHEASTERN ASSOCIATION OF GAME ANDFISHCOMMISSIONERS, 14, Biloxi, 1960. Proceedings. Biloxi, 1960. p.253-257.

SNOW, J.R. Results of further experiments on rearing largemouth bass fingerlings under controlled conditions. In: ANNUAL CONFERENCE OF THE SOUTHEASTERN ASSOCIATION OF GAME AND FISH COMMISSIONERS, 17., Hot Springs, 1963. Proceedings. Hot Springs, 1963. p.191-203

SNOW, J.R. The Oregon Moist Pellet as a diet for largemouth bass. The Progressive Fish Culturist, v.30, p.235, 1968.

Received July 11, 2002

Accepted July 31, 2003 